\title{
Characteristics of Vocal Loudness and Auditory Evoked Response in Patients with Parkinson's Disease
}

\author{
Chul-Hee Choi ${ }^{\mathrm{a}, \mathrm{b}}$, Chae Rim Park ${ }^{\mathrm{c}, \mathrm{d}}$, Seong Hee Choi ${ }^{\mathrm{a}, \mathrm{b}}$ \\ ${ }^{a}$ Department of Audiology and Speech-Language Pathology, College of Bio and Medical Sciences, Daegu Catholic University, Gyeongsan, Korea \\ ${ }^{b}$ Research Institute of Biomimetic Sensory Control and Catholic Hearing Voice Speech Center, Daegu Catholic University, Gyeongsan, Korea \\ 'Department of Audiology and Speech-Language Pathology, Graduate School of Health and Medical Science, Daegu Catholic University, Gyeongsan, \\ Korea \\ ${ }^{d}$ Department of Otorhinolaryngology, Kangbuk Samsung Hospital, Seoul, Korea
}

Correspondence: Seong Hee Choi, $\mathrm{PhD}$ Department of Audiology and Speech-Language Pathology, Institute of Biomimetic Sensory Control, and Catholic Hearing Voice Speech Center, Daegu Catholic University, 13-13 Hayang-ro, Hayang-eup, Gyeongsan 38430, Korea

Tel: +82-53-850-2542

Fax: +82-53-359-6780

E-mail: shgrace@cu.ac.kr

Received: October 5, 2019

Revised: November 27, 2019

Accepted: December 6, 2019

\begin{abstract}
Objectives: The objective of current study was to assess peripheral and central auditory functions in patients with Parkinson's disease (PD), and furthermore, to explore whether electrophysiological responses in the brain relate to reduced vocal loudness in patients with PD. Methods: A total of 24 subjects ( 12 normal and 12 IPD) participated. Pure tone audiometry and auditory evoked response as well as vocal loudness with sustained vowel /a/ and 'Kaeul' paragraph were measured. The stimulus level of $75 \mathrm{~dB} \mathrm{nHL}$ was used to measure the latency and amplitude of waves I, III and $\mathrm{V}$ of auditory brainstem response (ABR) and $\mathrm{Na}, \mathrm{Pa}, \mathrm{Nb}$, and $\mathrm{Pb}$ of auditory middle latency responses (AMLR) and P1, N1, P2, and N2 waves of auditory late latency responses (ALR). Results: The results showed that the hearing thresholds of idiopathic PD (IPD) were not different from the normal group. Significant softer vocal loudness was observed in IPD. In AMLR, significantly delayed latency in wave $\mathrm{Na}, \mathrm{Pa}$ and $\mathrm{Nb}$ and smaller $\mathrm{Na}$-Pa amplitudes were revealed in the IPD group. These results imply that delayed latency and smaller amplitude of AMLR waves can be linked to thalamus dysfunction in individuals with IPD. Finally, a significantly negative correlation between vocal loudness and wave III latency was found, suggesting that the softer the vocal loudness, the longer the latency of wave III. Conclusion: These results indicate that softer vocal loudness in individuals with IPD may be related to central auditory problems, not peripheral auditory dysfunction. Our findings suggest that electrophysiological methods provide valuable clinical information about sensory dysfunction in people with IPD.
\end{abstract}

Keywords: Parkinson's disease, Hearing threshold, Auditory evoked response, Auditory middle latency response, Vocal loudness
파킨슨병(Parkinson's disease, $\mathrm{PD}$ )은 음성과 말 증상을 보이는 신경학적 퇴행성 질환으로(Möbes et al., 2008), 환자 중 약 $90 \%$ 가 음성 및 말 문제로 고통을 받는다(Aronson, 1990). 특히, 음성 문제 는 말 문제보다 앞서 나타나는데, $\mathrm{PD}$ 환자들은 거칠고 기식적 음 성, 음량감소와 같은 음성 증상이 파킨슨증의 첫 징후로 나타날 수 있으며, 음량과 기본주파수의 변조의 부족으로 단음도(monotone) 와단음량(monoloudness)을 나타내는 운율의 문제를 보인다(Duffy,
2013). 질병이 진행됨에 따라 음량감소(hypophonia)가 과소운동 성 마비말장애의 말 문제와 동반될 때 $\mathrm{PD}$ 화자의 말 명료도는 매우 저하된다(Baker, Ramig, Luschei, \& Smith, 1998; Gath \& Yair, 1998; Perez, Ramig, Smith, \& Dromey, 1996; Solomon \& Charron, 1998). 이러한 PD 환자들의 말음성 문제를 치료하기 위하여 다양한 치료 법이 사용되어져 왔는데, 도파민 약물치료는 음량을 증가시키거나 마비말장애 증상을 개선시키는데 도움을 주지 못한다고 보고되었 
으며(Rascol et al., 2003; Romito \& Albanese, 2010), 뇌심부자극술 은 음성강도나 말 문제에 미치는 효과가 연구자마다 차이를 보이고 있다(Choi, 2012; Klostermann et al., 2008). 한편, 음성강도 증가에 초점을 둔 리실버만 음성치료(Lee Silverman Voice Treatment, LSVT)는 환자가 좀 더 큰 목소리를 내도록 훈련함으로써 PD 환자 의 호흡을 개선시키고, 성대 내전을 도모하여 음성강도, 음질 및 말 명료도를 향상시키는 효과가 있다고 보고되었다(Choi, 2011; Fox et al., 2002; Ramig, 1994). 최근에는 실리콘 튜브를 물에 넣고 발성을 연습하는 Lax Vox 음성치료가 PD 환자의 음성강도를 증진시키고 말명료도를 개선하는데 효과적이라고 보고되었다(Chae, Choi, Choi, \& Lee, 2019). 이처럼 PD 환자에 있어 음성강도의 감소와 음 질 저하는 파킨슨병 환자들의 의사소통과 삶의 질에 영향을 미친 다(Guimaraes, Cardoso, Pinto, \& Ferreira, 2017).

이외에 $\mathrm{PD}$ 환자들은 감소된 자신의 음량을 부인하여 지속적으 로 작은 소리를 내고, 이것은 감소된 운동 산출로 이어져 큰 소리로 말하는 데 어려움이 있게 된다. 뿐만 아니라 음량을 조절하는 데 어 려움이 있음이 보고되었는데(Ho, Bradshaw, \& Iansek, 2000; Ho, Bradshaw, Iansek, \& Alfredson, 1999), 소음이 있는 상황에서도 음 성 크기를 증가시키지 못하거나, 큰 소리의 청각적 피드백을 받았을 때 자신의 말소리 음량을 줄이지 못한다고 하였다. 또한, 최근 PD 환자들의 말음성 문제와 관련된 신경병리학적 병변의 관련성에 관 한 fMRI 연구에 의하면, PD 환자들이 외적인 청각피드백을 모니터 링하는 능력이 감소됨을 보고하였으며, 자가 모니터링 기제의 기능 이상과 함께 선조체-전전두엽 연결(striato-prefrontal connectivity) 의 감소가 음량감소와 관련 있음을 시사하였다(Arnold, Gehrig, Gispert, Seifried, \& Kell, 2014; Mollaei, Shiller, \& Gracco, 2013). 또 한, Fox 등(2002)은 음량감소(hypophonia)가 기저핵 기능이상으 로 감소된 운동구동력에 기인하며, 이것이 말소리 음량을 감소시키 고 단음도와 단음량의 운율장애를 나타내는 원인이 된다고 하였다. 운율 산출은 기저핵 회로와 관련이 있는데(Cancelliere \& Kertesz, 1990), 기저핵은 운율 산출을 조절하는 감각운동회로의 한 부분일 뿐만 아니라 감정 상태의 기능으로서 말의 멜로디를 조절한다 $(\mathrm{Pi}-$ chon \& Kell, 2013). PD 환자들의 음량감소는 대뇌피질, 대뇌피질 하 영역의 회백질, 전두엽과 추체로 및 추체외로를 포함한 운동로 의 병변으로 인해 발생한다고 하였으며(Liotti et al., 2003; Logemann, Fisher, Boshes, \& Blonsky, 1978), 이외에도 Blacker (2003) 는 음량감소가 전외측 시상(thalamus)의 혈관성 병변과 관련이 있 다고 보고하였다. 이를 종합해 볼 때, 말소리 크기는 운동인식(motor awareness)이나 산출 혹은 청지각적, 체성감각피드백에 의해 조 절될 수 있는데, 이러한 $\mathrm{PD}$ 환자들의 말산출 동안 음량조절장애는
이러한 감각운동통합의 기능이상에 의해 초래될 수 있다. 따라서, 본 연구에서는 PD 환자들의 음성강도의 저하가 자신의 음성을 듣 고 모니터링하는 말초신경의 청각적 피드백의 문제인지 혹은 중추 감각처리장애인지 비침습적인 방법인 전기생리학적 방법을 통해 살펴보고자 한다.

청성유발반응은 중추청각처리장애, 언어장애, 치매, 인지장애 등과 같은 다양한 장애영역에서 장애를 가진 환자군의 청각 말초 와 중추신경계의 특성을 조사하는 객관적이고 임상적으로 유용한 평가도구로 사용되어 왔다(Sanju \& Kumar, 2016). 청각 기관은 자 극, 경험, 손상, 병, 치료, 학습 및 훈련과 같은 다양한 환경 변화에 반응하여 그 구조와 기능을 재조직하거나 변화시킬 수 있는 잠재 력, 즉 신경가소성(neuroplasticity)을 가지고 있으며(Choi, 2015), 청성유발반응은 이러한 뇌 또는 중추신경계의 신경가소성을 측정 할 수 있는 유용한 임상도구로 알려져있다(Choi, Jang, \& Choi, 2015; Jang, Choi, \& Choi, 2017). 청성유발반응은 청각과 관련된 말 초 및 중추신경계에서 생성되는 일련의 전기반응을 측정하는 전기 생리학적 검사로 피검사자의 행동반응을 필요로 하지 않는 비침습 적이고 객관적인 청력검사이다(Choi et al., 2015; Jang et al., 2017). 청성유발반응은 주로 외인성과 내인성 반응 또는 음향자극에 대 한 반응의 잠복기(latency)에 따라 분류할 수 있는데(Sanju \& Ku$\operatorname{mar}, 2016)$, 외인성 반응은 일차적으로 외부의 특별한 자극, 즉 사 건관련전위(event-related potentials)에 의해 유발된 전기반응을 나 타내지만 내인성 반응은 인지 또는 지각에 의해 유발되는 내부의 전기반응이다. 또한 청성유발반응은 음향자극에 유발되는 전기반 응의 잠복기에 따라 청성초기, 청성중기 및 청성후기 반응으로 분 류된다(Choi et al., 2015; Jang et al., 2017). 청성 초기 반응(auditory early response)은 음향자극 제시 후 $10 \mathrm{~ms}$ 이내의 잠복기에 나 타나는 전기반응으로 와우의 유모세포와 청신경에서 유발되는 전 기와우도(electrocochleography)와 청신경과 뇌간에서 발생하는 Wave I, III, V 파형을 나타내는 청성뇌간반응 (auditory brainstem response, $\mathrm{ABR}$ )으로 구성된다. 청성중기반응(auditory middle latency response, AMLR)은 음향자극 제시 후 $12-50 \mathrm{~ms}$ 사이의 잠 복기에서 유발되는 전기 반응으로 $\mathrm{Na}, \mathrm{Pa}, \mathrm{Nb}, \mathrm{Pb}$ 파로 구성되며 중뇌와 시상에서 발생한다. 청성후기반응(auditory late response, $\mathrm{ALR})$ 은 음향자극 지시 후 50-500 ms 사이의 잠복기에서 유발되고 $\mathrm{P} 1, \mathrm{~N} 1, \mathrm{P} 2, \mathrm{~N} 2$ 로 구성되며 대뇌피질에서 발생하는 전기반응을 나 타낸다.

따라서 본 연구는 PD 유무에 따라 음성강도 및 청력의 상태에 차이가 있는지 살펴보고, 아울러 전기생리학적 검사를 사용하여 청성유발반응의 차이가 있는 살펴봄으로써, 말초 및 중추감각처리 
손상 여부를 조사하고, $\mathrm{PD}$ 환자의 감소된 음성강도와 어떠한 상관 관계가 있는 지 살펴보고자 한다.

\section{연구방법}

\section{연구대상}

본 연구의 대상자는 파킨슨병 환우회 소속으로 신경과 전문의로 부터 특발성 파킨스병(idiopathic Pakinson's disease, IPD)으로 진 단받은 총 12 명(남성 5 명, 여성 7명)으로 평균연령은 $62.8 \pm 8.04$ 세 이었다. 또한, 한국판 간이정신상태판별검사(Korean version of Mini Mental State Examination, K-MMSE)의 결과 25점 이상의 대 상자들만이 이 연구에 포함되었고(Ramig, Countryman, Thompson, \& Horii, 1995), 청성유발반응을 검사하기 때문에 PD 이외의 다른 신경학적인 문제가 없고 다른 말/언어 문제 또는 다른 행동 문 제를 가지지 않고 청성유발반응에 영향을 줄 수 있는 수술을 받지 않은 대상자만을 연구대상으로 선정하였다. 대상자들은 신경과에 서 항파킨슨 약물이나 도파민 분비에 도움을 주는 약물을 복용 중 이었고 아침 첫 약물 복용 후 3 시간 이내에 검사를 실시하였다. 한 편, 정상 대조군은 성과 연령을 일치하여 파킨슨병으로 진단 받지 않고 K-MMSE검사 결과 25점 이상으로 인지 문제가 없으며, 청력 에 문제를 보이지 않고 신경학적 문제를 보이지 않는 정상 노인을 대상으로 하였으며, 평균연령은 $62.8 \pm 9.29$ 세였고 총 12 명이 참가 하였다. 모든 연구대상자들은 대구가톨릭대학교 생명윤리위원회 (Institutional Review Board)의 심의 승인 하에 모집 및 선정되었으 며(No. CUIRB-2018-0078) 환자군의 정보는 Table 1과 같다.

Table 1. Participants' information

\begin{tabular}{lccccc}
\hline Subject No. & Age & Gender & H\&Y stage & $\begin{array}{c}\text { Years after } \\
\text { diagnosis }\end{array}$ & $\begin{array}{c}\text { Use of treat- } \\
\text { ment drug }\end{array}$ \\
\hline 1 & 53 & F & 1 & 2 & 0 \\
2 & 53 & F & 2 & 10 & 0 \\
3 & 57 & M & 3 & 16 & 0 \\
4 & 59 & M & 2 & 10 & 0 \\
5 & 67 & F & 2 & 7 & 0 \\
6 & 68 & M & 1 & 6 & 0 \\
7 & 76 & F & 2 & 11 & 0 \\
8 & 56 & F & 2 & 10 & 0 \\
9 & 59 & M & 2 & 12 & 0 \\
10 & 61 & F & 2 & 5 & 0 \\
11 & 71 & M & 2 & 2 & 0 \\
12 & 72 & F & 2 & 10 & 0 \\
\hline
\end{tabular}

$\mathrm{H} \& \mathrm{Y}$ stage $=$ Hoehn and $Y$ ahr stage.

\section{연구 절차}

음성강도 측정

음성강도 자료는 소음이 차단된 방음실에서 Spielman, Ramig, Mahler, Halpern과 Gavin (2007)의 연구에서 사용되었던 고급 품 질의 type I 소음계(sound level meter)인 디지털 소음계(2250 Mod$\mathrm{el}, \mathrm{B} \& \mathrm{~K}, \mathrm{Germany})$ 를 사용하여 측정하였다. 음성강도를 측정하기 위하여 대상자의 입과 소음계 거리는 $30 \mathrm{~cm}$ 의 거리를 유지하도록 하였다. 음성강도는 선행 연구의 연구에서 사용되었던 방법으로 녹 음되었다. 이 방법에서 데이터 수집기는 각 음성작업 전체에 걸쳐 1 초 간격으로 표시되는 피크 SPL 정보를 기록하고 과제 간 입으로부 터 소음계까지의 거리를 지속적으로 모니터링한다. 이 방법은 소프 트웨어 유도 측정과 유사한 SPL을 산출하며(Ramig et al., 1995) 이 전 선행 연구에서 리실버만 음성치료 효과를 살펴보기 위해 음성강 도 측정을 위해 사용한 절차를 따라 시행하였다(Ramig, Sapir, Fox, \& Countryman, 2001). 모든 파킨슨병 환자들은 대체적으로 약물 복용 후 약 1 시간 후에 자료를 측정하였다.

음성 강도는 평상시 모음 / / / 연장 발성과 연속 구어는 '가을 표 준 문단을 이용하여 측정하였고, 모든 음성 자료는 2 번씩 반복하도 록 하였다. 모음// 연장 발성은 편안한 목소리로 5 초간 발성하도록 하였으며, 연속 구어는 '가을' 문단 중 첫 문장인 '우리나라의 가을 은 참으로 아름답다' 를 낭독하도록 하였다. 이때 대상자가 앉은 자 세에서 글씨가 보이도록 참여자 눈 높이에서 보여 주고 평상 시 목소 리의 음높이와 강도로 읽도록 하였다. 글씨가 잘 보이지 않는 경우 는 평가자가 옆에서 먼저 읽어 주고 따라말하기를 통해 말하도록 하 였다. 음성강도는 각 피크 SPL의 평균을 음성강도로 사용하였다.

\section{순음청력검사}

연구대상자의 청력역치를 얻기 위하여 소음이 통제된 방음부스 안에서 양이의 순음청력검사를 실시하였다. 순음청력검사는 순음 청력검사기기(Starkey Acoustic Analyzer AA1200, Qualitine, USA)를 사용하여 $250-8,000 \mathrm{~Hz}$ 까지 옥타브 간격으로 주파수를 측정하였다.

\section{청성유발반응검사}

청성유발반응(auditory evoked responses, AERs)은 GSI사의 Audera System (Grason-Stadler, Eden Prairie, MN, USA)을 사용 하여 측정하였다. 대상자는 방음부스 안에 있는 안락의자에 편안 한 자세로 누웠고, 전극을 붙일 두피는 알코올 솜으로 소독한 후 면 봉을 사용하여 젤인 뉴프렙(Nuprep)으로 두피를 닦은 후 두피 부 분에 전도 크림을 사용하여 디스크형 전극(disc type electrode)을 부착하였다. 청성유발반응을 얻기 위하여 활성 전극 또는 양전극 
으로 불리는 비전환전극(non-inverting electrode)은 이마(forehead)에, 음전극 또는 기준전극으로 불리는 전환전극(inverting electrode)은 양쪽의 귓불(ear lobes)에, 그리고 접지 전극(ground electrode)은 낮은 이마(low forehead)에 각각 부착하였다. 청성유 발반응에서는 청성뇌간반응(ABR), 청성중기반응(AMLR) 및 청성 후기반응(ALR)를 측정하였다.

청성뇌간반응, 청성중기반응, 및 청성후기반응을 얻기 위해서 서 로 다른 자극 변수(stimulus parameter)의 설정이 필요한데 본 연 구에서 사용된 자극 변수는 Table 2와같다.

청성뇌간반응을 측정하기 위해 자극은 $0.1 \mathrm{~ms}$ 클릭음, 자극률은 $13.1 / \mathrm{s}$, 자극 강도는 $75 \mathrm{~dB} \mathrm{nHL}$, 자극 극성은 교류, 전체 스왑의 수 는 2,000 , 대역통과필터는 $100-3,000 \mathrm{~Hz}$ 로 설정하여 삽입형 이어 폰(insert earphone)을 사용하였다. 청성중기반응의 경우, 자극은 $0.1 \mathrm{~ms}$ 클릭음, 자극률은 7.1/s, 자극강도는 $75 \mathrm{~dB} \mathrm{nHL}$, 자극 극성 은 교류, 전체 스왑의 수는 2,000 , 대역통과필터는 $10-250 \mathrm{~Hz}$ 로 설 정하였고 삽입형 이어폰(insert earphone)을 사용하여 측정하였다. 마지막으로 청성후기반응의 경우, 자극은 $0.1 \mathrm{~ms}$ 클릭음, 자극률은 $0.5 / \mathrm{s}$, 자극강도는 $75 \mathrm{~dB} \mathrm{nHL}$, 자극극성은 교류, 전체 스왑의 수는 100 , 대역통과필터는 $10-100 \mathrm{~Hz}$ 로 설정되어 삽입형 이어폰(insert earphone)을 사용하여 측정하였다. 청성뇌간반응에서는 Wave I, III, V의 잠복기(latency)와 진폭(amplitude), 청성중기반응에서는 $\mathrm{Na}, \mathrm{Pa}, \mathrm{Nb}$ 및 $\mathrm{Pb}$ 의 잠복기와 진폭, 그리고 청성후기반응에서는 $\mathrm{N} 1, \mathrm{P} 1, \mathrm{~N} 2$ 및 P2의 잠복기와 진폭을 분석하였으며, 평균과 표준편 차로 제시하였다.

\section{통계분석}

수집된 자료는 SPSS version 22.0을 사용하여 통계 처리하였고, 파킨슨병 유무에 따른 음성강도와 청성유발반응의 차이를 비교하 기 위하여 Mann-Whitney $U$-test를 사용하였으며 통계적 유의 수 준은.05수준에서 검증하였다.

Table 2. Stimulus parameters and detail information

\begin{tabular}{lccc}
\hline Parameters & ABR & AMLR & ALR \\
\hline Stimulus type (ms click) & 0.1 & 0.1 & 0.1 \\
Stimulus rate (per second) & 13.1 & 7.1 & 0.5 \\
Stimulus level (dB nHL) & 75 & 75 & 75 \\
Stimulus polarity & Alternating & Alternating & Alternating \\
Total sweeps & 2,000 & 2,000 & 100 \\
Band pass filter (Hz) & $100-3,000$ & $10-250$ & $10-100$ \\
Transducer type & Insert earphone & Insert earphone & Insert earphone
\end{tabular}

$A B R=$ auditory brainstem response; $A M L R=$ auditory middle latency response; $A L R=$ auditory late response.

\section{연구결과}

\section{순음청력검사 결과}

순음청력검사 결과, IPD군과 정상군의 청력역치는 유의미한차이 를 보이지 않았다 $(p>.05) . \mathrm{IPD}$ 군의 평균 청력역치는 $22.75 \pm 1.54$ $\mathrm{dB}$ HL이었으며, 정상군의 평균 청력역치는 $23.92 \pm 1.44 \mathrm{~dB} \mathrm{HL}$ 이 었다. Mann-Whitney $U$-test결과, IPD군과 정상군 간 평균 청력역 치가 통계적으로 유의미한 차이는 없었다 $(p>.05)$.

\section{음성강도 평가 결과}

$\mathrm{IPD}$ 군과 정상군 간 모음 / / / 연장 발성 시 음성강도의 결과는 Figure 1과 같다. 모음 / / / 연장 발성 시, IPD 군의 평균 음성강도는 $42.66 \pm 4.07 \mathrm{~dB}$, 정상군의 평균 음성강도는 $56.67 \pm 3.65 \mathrm{~dB}$ 이었으

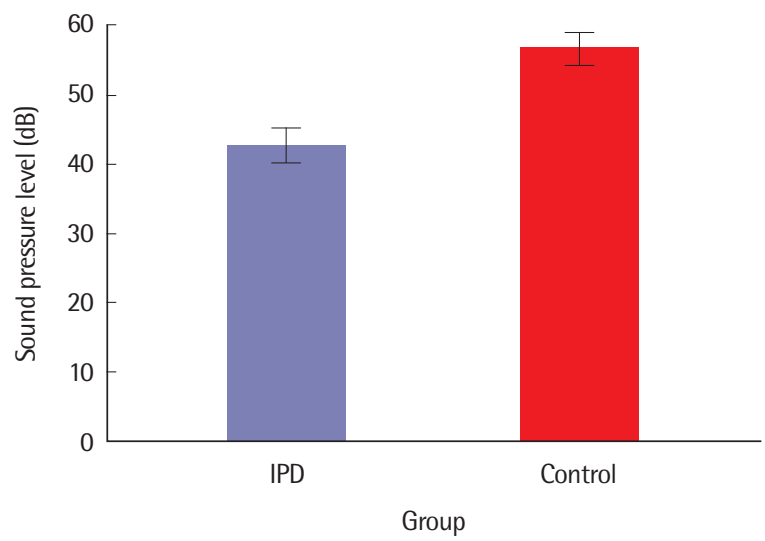

Figure 1. Comparison of mean vocal loudness in sustained vowel /a/ between IPD and normal groups.

IPD = idiopathic Parkinson's disease.

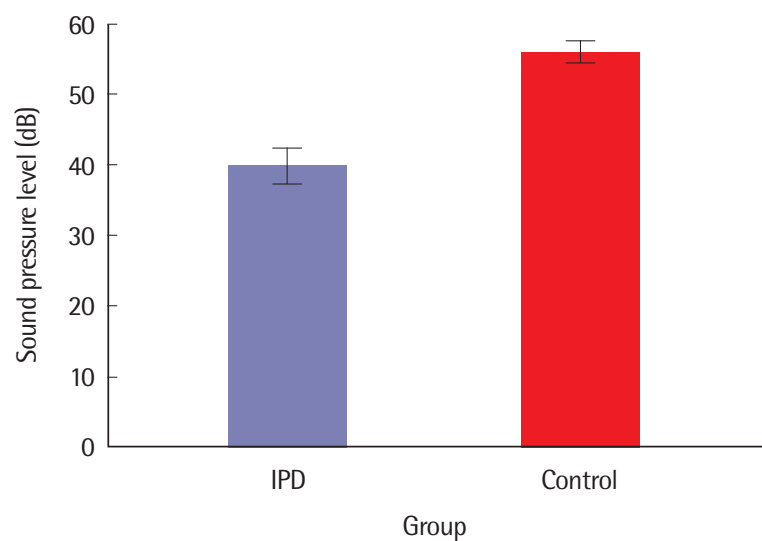

Figure 2. Comparison of mean vocal loudness in a standardized 'Kaeul' sentence between IPD and normal groups. $I P D=$ idiopathic Parkinson's disease. 
며, 평균 음성강도는 IPD군이 통계적으로 유의미하게 낮은 음성강 도를 보였다 $(p<.001)$.

$\mathrm{IPD}$ 군과 정상 노인군 간 표준 문단 '가을' 중 문장 낭독 시 평균 음성강도 결과는 Figure 2와 같다. 표준 문단 '가을' 중 문장읽기 과 제에서 평균 음성강도는 $\mathrm{IPD}$ 군은 $39.75 \pm 4.02 \mathrm{~dB}$, 정상 노인군은 $56.00 \pm 2.33 \mathrm{~dB}$ 이었다. Mann-Whitney $U$-test 결과, IPD군의 평균 음성강도는 정상 대조군과 비교해 보았을 때 유의미하게 낮았다 $(p<.05)$.

\section{청성유발반응평가 결과}

청성뇌간반응평가 결과

파킨슨병의 유무에 따른 청성뇌간반응(ABR)의 Wave I, III, V의 잠복기와 진폭의 차이를 비교하였다. ABR Wave I, III, V의 잠복기 를 살펴보면, $\mathrm{ABR}$ Wave I의 잠복기에서 $\mathrm{IPD}$ 군은 $1.65 \pm 0.24 \mathrm{~ms}$, 정상군은 $1.62 \pm 0.2 \mathrm{~ms}$ 이었다. $\mathrm{ABR}$ Wave III의 잠복기 경우, $\mathrm{IPD}$ 군은 $3.52 \pm 0.27 \mathrm{~ms}$, 정상군은 $3.41 \pm 0.4 \mathrm{~ms}$ 이었고 $\mathrm{ABR}$ Wave $\mathrm{V}$ 의 잠복기 경우, $\mathrm{IPD}$ 군은 $5.61 \pm 0.32 \mathrm{~ms}$ 이고 정상군은 $5.43 \pm 0.25$ $\mathrm{ms}$ 이었다. $\mathrm{ABR}$ Wave I, III, V에서 IPD군의 평균 잠복기는 정상노 인군과 통계적으로 유의미한 차이를 보이지 않았다 $(p>.05)$.

또한, ABR Wave I, III, V의 진폭을 비교한 결과, ABR Wave I의 진폭에서 $\mathrm{IPD}$ 군은 $0.31 \pm 0.17 \mu \mathrm{V}$ 이고 정상군은 $0.32 \pm 0.16 \mu \mathrm{V}$ 이 었다. ABR Wave III의 진폭에서 IPD군은 $0.45 \pm 0.11 \mu \mathrm{V}$ 이고 정상 군은 $0.47 \pm 0.15 \mu \mathrm{V}$ 이었고 $\mathrm{ABR}$ Wave $\mathrm{V}$ 의 진폭에서 $\mathrm{IPD}$ 군은 0.59 $\pm 0.10 \mu \mathrm{V}$, 정상군은 $0.66 \pm 0.11 \mu \mathrm{V}$ 이었다. ABR Wave I, III, $\mathrm{V}$ 에서 $\mathrm{IPD}$ 군의 평균 진폭은 정상군과 통계적으로 유의미한 차이는 없었 다( $p>$.05).

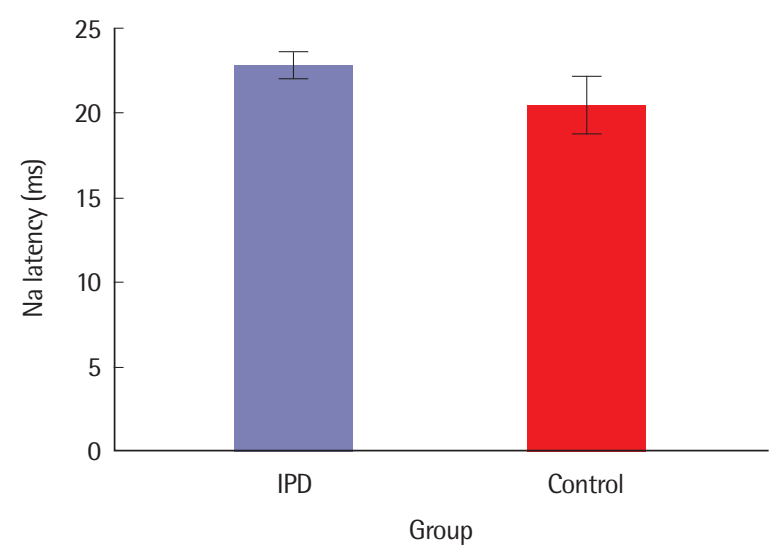

Figure 3. Comparison of mean Na latency in auditory middle latency response between IPD and normal groups.

IPD= idiopathic Parkinson's disease.

\section{청성중기반응평가 결과}

파킨슨병의 유무에 따른 청성중기반응(AMLR)의 $\mathrm{Na}, \mathrm{Pa}, \mathrm{Nb}$, $\mathrm{Pb}$ 의 잠복기와 진폭의 차이를 비교하였다. $\mathrm{Na}, \mathrm{Pa}, \mathrm{Nb}, \mathrm{Pb}$ 의 잠복 기를 비교했을 때, $\mathrm{IPD}$ 군과 정상군의 평균 $\mathrm{Na}$ 잠복기의 결과는 Figure 3 과 같다. $\mathrm{Na}$ 의 잠복기에서 $\mathrm{IPD}$ 군은 $22.77 \pm 1.26 \mathrm{~ms}$, 정상 군은 $20.41 \pm 2.70 \mathrm{~ms}$ 이었다. $\mathrm{Na}$ 의 잠복기는 $\mathrm{IPD}$ 군과 정상군에서 통계적으로 유의미한 차이를 보였으며 $(p<.05) . \mathrm{IPD}$ 군의 $\mathrm{Na}$ 잠복 기는 정상군과 비교해 볼 때 유의미하게 길었다.

$\mathrm{IPD}$ 군과 정상군의 평균 $\mathrm{Pa}$ 잠복기의 결과는 Figure 4 와 같다. $\mathrm{Pa}$ 의 잠복기에서 $\mathrm{IPD}$ 군은 $36.21 \pm 2.20 \mathrm{~ms}$, 정상군은 $29.91 \pm 2.87$ $\mathrm{ms}$ 이었다. $\mathrm{Pa}$ 의 잠복기는 $\mathrm{IPD}$ 군과 정상군 간 통계적으로 유의미 한 차이를 보였으며 $(p<.001), \mathrm{IPD}$ 군의 $\mathrm{Pa}$ 잠복기는 정상대조군과 비교해 볼 때 유의미하게 길었다.

또한, $\mathrm{IPD}$ 군과 정상군의 평균 $\mathrm{Nb}$ 잠복기의 결과는 Figure 5 와 같다. $\mathrm{Nb}$ 의 잠복기에서 $\mathrm{IPD}$ 군은 $43.44 \pm 3.29 \mathrm{~ms}$, 정상군은 40.27 $\pm 0.70 \mathrm{~ms}$ 이었다. $\mathrm{Nb}$ 의 잠복기는 $\mathrm{IPD}$ 군과 정상군에서 통계적으 로 유의미한 차이를 보였고 $(p<.05), \mathrm{IPD}$ 군의 $\mathrm{Nb}$ 잠복기가 정상대 조군과 비교해 볼 때 길게 나타났다.

한편, $\mathrm{AMLR}$ 의 $\mathrm{Pb}$ 잠복기를 비교한 결과, $\mathrm{IPD}$ 군은 $59.66 \pm 2.60$ $\mathrm{ms}$, 정상군은 $55.89 \pm 5.68 \mathrm{~ms}$ 이었으며, $\mathrm{AMLR}$ 의 $\mathrm{Pb}$ 에서 $\mathrm{IPD}$ 군의 평균 잠복기는 정상군과 통계적으로 유의한 차이는 보이지 않았다.

파킨슨병의 유무에 따른 AMLR Pa-Na, Pa-Nb의 파간 진폭의 차이를 비교하였으며, 평균 $\mathrm{Pa}-\mathrm{Na}$ 파간 진폭의 결과는 Figure 6과 같다. $\mathrm{Pa}-\mathrm{Na}$ 의 파간 진폭에서 $\mathrm{IPD}$ 군은 $0.83 \pm 0.39 \mu \mathrm{V}$, 정상군은 $1.22 \pm 0.43 \mu \mathrm{V}$ 이었다. $\mathrm{Pa}-\mathrm{Na}$ 의 파간 진폭이 양의 값을 보였으며 이 는 $\mathrm{Pa}$ 의 진폭이 $\mathrm{Na}$ 의 진폭보다 상대적으로 크다는 것을 의미한다.

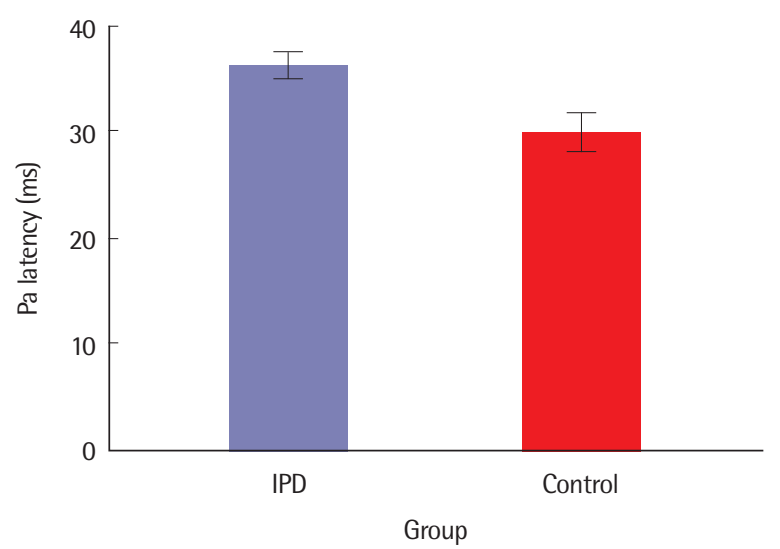

Figure 4. Comparison of mean Pa latency in auditory middle latency response between IPD and normal groups.

IPD= idiopathic Parkinson's disease. 


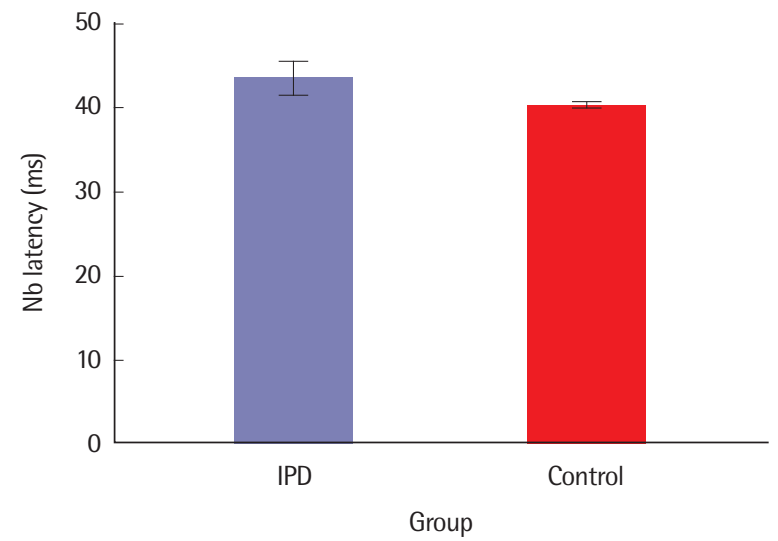

Figure 5. Comparison of mean $\mathrm{Nb}$ latency in auditory middle latency response between IPD and normal groups.

IPD = idiopathic Parkinson's disease.

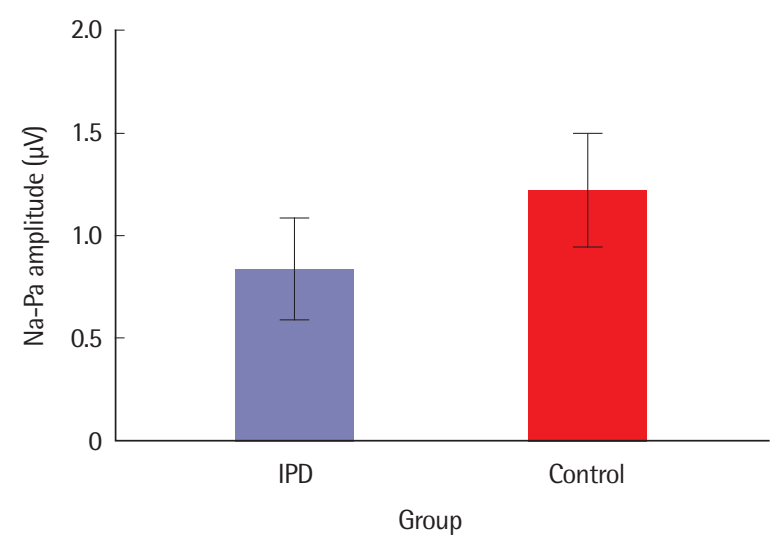

Figure 6. Comparison of mean Pa-Na amplitude in auditory middle latency response between IPD and normal groups.

IPD = idiopathic Parkinson's disease.

$\mathrm{Pa}-\mathrm{Na}$ 파간 진폭은 $\mathrm{IPD}$ 군과 정상군 간 통계적으로 유의미한 차이 를 보였으며 $(p<.05), \mathrm{IPD}$ 군의 $\mathrm{Pa}-\mathrm{Na}$ 파간 진폭이 정상대조군과 비 교해 볼 때 유의미하게 작게 나타났다.

마지막으로, 평균 $\mathrm{Pa}-\mathrm{Nb}$ 파간 진폭의 경우, $\mathrm{IPD}$ 군은 $1.15 \pm 1.01$ $\mu \mathrm{V}$, 정상군은 $1.40 \pm 0.67 \mu \mathrm{V}$ 이었다. $\mathrm{Pa}-\mathrm{Nb}$ 의 파간 진폭이 양의 값 을 보이는 것은 $\mathrm{Pa}$ 의 진폭이 $\mathrm{Nb}$ 의 진폭보다 상대적으로 큰 것을 의 미하는데 본 연구에서 $\mathrm{Pa}-\mathrm{Nb}$ 파간 진폭은 IPD과 정상군 간 통계 적으로 유의한 차이를 보이지 않았다.

\section{청성후기반응평가 결과}

파킨슨병의 유무에 따른 청성후기반응(ALR)의 $\mathrm{P} 1, \mathrm{~N} 1, \mathrm{P} 2, \mathrm{~N} 2$ 의 잠복기와 진폭의 차이를 비교한 결과, $\mathrm{ALR}$ 의 $\mathrm{P} 1$ 의 잠복기는 IPD 군은 $52.49 \pm 10.42 \mathrm{~ms}$, 정상군은 $51.22 \pm 15.02 \mathrm{~ms}$ 이었고, ALR의

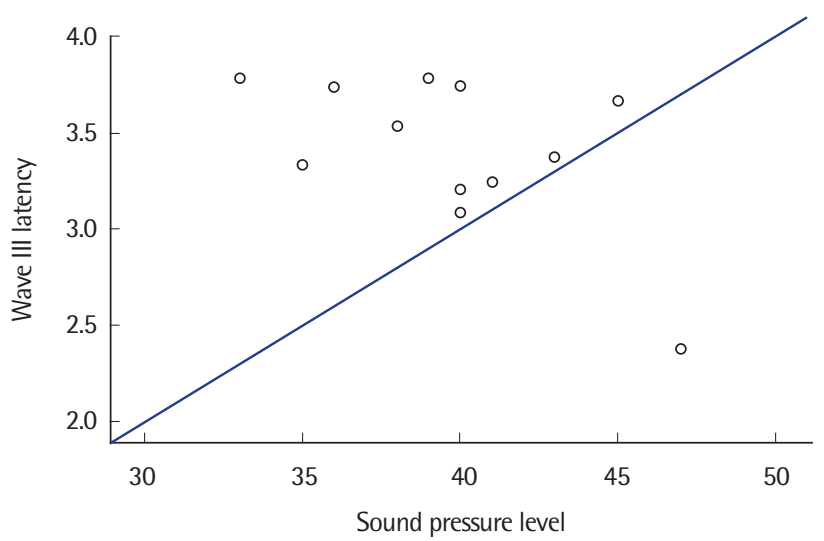

Figure 7. Correlation between wave III latency and sound pressure level in idiopathic Pakinson's disease group.

$\mathrm{N} 1$ 의 잠복기는 $\mathrm{IPD}$ 군은 $105.91 \pm 9.79 \mathrm{~ms}$, 정상군은 $101.72 \pm 20.37$ $\mathrm{ms}$ 이었다. $\mathrm{ALR}$ 의 $\mathrm{P} 2$ 의 잠복기는 $\mathrm{IPD}$ 군은 $161.94 \pm 21.96 \mathrm{~ms}$, 정상 군은 $174.33 \pm 26.22 \mathrm{~ms}$ 이었고, $\mathrm{ALR}$ 의 $\mathrm{N} 2$ 의 잠복기를 비교한 결 과, IPD군은 $259.13 \pm 20.62 \mathrm{~ms}$, 정상군은 $251.08 \pm 23.96 \mathrm{~ms}$ 이었 다. 하지만, ALR의 P1, N1, P2, N2의 잠복기를 비교한 결과, IPD군 은 정상군과 통계적으로 유의미한 차이는 보이지 않았다.

또한 ALR의 N1-P2의 파간 진폭의 경우, $\mathrm{IPD}$ 군은 $4.45 \pm 1.60 \mu \mathrm{V}$, 정상인군은 $4.31 \pm 2.32 \mu \mathrm{V}$ 이었다. ALR의 N1-P2의 파간 진폭은 양 의 값을 보였는데 이는 N1의 진폭이 P2의 것보다 크다는 것을 나타 낸다. 하지만, ALR의 N1-P2의 파간 진폭은 IPD군이 정상군보다 통계적으로 유의미한 차이는 보이지 않았다.

\section{파킨슨병 환자의 음성강도와 청성유발반응의 상관관계}

$\mathrm{IPD}$ 군의 음성 강도와 청성유발반응의 상관관계는 Figure 7과 같다. 이러한 부적 상관관계는 다른 모든 파에서는 관찰되지 않았 으나. 오직 ABR Wave III의 잠복기에만 관찰되었다 $(p<.05)$. 즉, 파 킨슨병 환자의 음성 강도가 작을수록 ABR Wave III의 잠복기도 증 가하였다.

\section{논의 및 결론}

청성유발반응은 신경학적 감각장애를 가진 환자들의 구심성(afferent)기능을 객관적으로 평가하는 데 사용되어져 왔다(Goodin \& Aminoff, 1987). 본 연구는 청각의 말초와 중추신경계에서 일어 나는 변화들을 감지할 수 있는 전기생리학적인 검사 중 하나인 청 성유발반응을 통해 $\mathrm{PD}$ 환자의 감각처리 특성을 살펴보았다. 아울 러 $\mathrm{PD}$ 환자의 말음성 문제 중 음성강도와 청성유발반응 측정치 간 
상관성을 살펴 보았다.

순음청력검사 결과, $\mathrm{IPD}$ 군의 평균 청력역치는 정상노인군 보다 조금 낮았지만 두 집단 간 유의미한 차이는 나타나지 않아 두 집단 간 청력의 문제는 차이가 없는 것으로 나타났다. 그러나, 최근 감각 신경성 난청을 가진 노인의 청력역치를 비교한 한 선행연구에서 따 르면, 파킨슨병 노인환자군의 청력역치는 정상대조군보다 더 높았 지만 통계적으로 유의미한 차이가 없다는 결과를 보고하여 본 연구 와 비슷한 결과를 보였다(Folmer, Vachhani, Theodoroff, Ellinger, \& Riggins, 2017). 또한, Yýlmaz 등(2009)의 연구에 의하면, $4-8 \mathrm{kHz}$ 의 주파수 범위에서 $\mathrm{PD}$ 환자군의 청력역치가 오히려 정상노인군보 다 통계적으로 유의미하게 높았다고 보고하였다. 이러한 선행연구 마다 IPD환자군의 청력역치 결과의 차이는 각 연구대상자의 모집 군의 차이로 발생한 것으로 보인다. 본 연구에서는 감각신경성 난청 을 가지지 않는 $\mathrm{PD}$ 환자군을 정상군과 비교하여 청력역치를 비교 하였는데 그 이유는 난청이 없는 PD 환자군과 정상대조군을 비교 한다면 파킨슨병의 유무가 뇌의 전기반응에 직접적으로 미치는 영 향을 분명하게 조사할수 있기 때문이다.

본 연구에서 모음// / 연장 발성과 표준 문단인 '가을'문단 발성 시 측정된 음성강도는 $\mathrm{IPD}$ 군과 정상대조군에서 통계적으로 유의 미한 차이를 보였으며, 모음과 문장 과제 모두에서 $\mathrm{IPD}$ 군의 평균 음성강도가 정상대조군보다 유의하게 나타나 본 연구의 IPD군의 낮은 음성강도의 결과는 다른 선행연구들과 일치하였다(Ramig, Fox, \& Sapir, 2008). 이러한 낮은 음성강도는 PD 환자의 호흡 및 후 두근육의 강직, 성대근육의 협응운동 저하, 후두와 성대진동의 불 안정, 또는 불규칙적인 성대의 접촉 등으로 기인될 수 있다(Baker et al., 1998; Gath \& Yair, 1988; Solomon \& Charron, 1998). 하지만, 본 연구에서 청성유발반응 결과, 청성뇌간반응의 Wave I, II, V의 잠복 기는 $\mathrm{IPD}$ 군과 정상대조군에서 통계적으로 유의미한 차이를 보이 지는 않았으나, $\mathrm{IPD}$ 군의 잠복기가 정상대조군보다 더 지연된 결과 를 보였다. O'Donnell, Squires, Martz, Chen과 Phay (1987)의 연구 에서는 청성뇌간반응 Wave I, III, V의 잠복기가 정상군과 $\mathrm{PD}$ 환자 군 간 차이를 보이지 않았으나, 반면에 다른 선행연구에서는 본 연 구의 청성뇌간반응 결과와는 일치하지 않는 결과를 보였는데(Bindi et al., 1987; Liu et al., 2017; Yýlmaz et al., 2009), Yýlmaz 등(2009) 의 연구에서는 IPD군의 청성뇌간반응의 Wave $\mathrm{V}$ 잠복기와 Wave $\mathrm{I}-\mathrm{V}$ 의 파간 잠복기는 정상대조군과 통계적으로 유의미한 차이를 보였고, Bindi 등(1987)의 연구에서는 PD 환자의 Wave III과 V의 잠복기와 Wave III-V와 I-V의 파간 잠복기가 정상대조군의 것보다 더 지연되었다고 보고하였다. 이러한 연구결과의 차이는 각 연구에 참가한 대상자들의 파킨슨병인의 차이, 약물 복용의 여부, 대상자
수의 차이 및 파킨슨병의 중증도인 $\mathrm{H \& Y}$ 의 단계의 차이로 볼 수 있 는데 본 연구에 참여한 $\mathrm{PD}$ 환자군은 대부분 $\mathrm{H} \& \mathrm{Y}$ 가 2단계에 해당 하는 비교적 초기 단계에 속한 환자가 대부분이었다. 특히, 본 연구 에 참가한 모든 대상자들은 L-dopa 약물을 복용하고 있으므로 정 상대조군과 차이가 줄어들 수 있는 가능성이 있다. 따라서 후속 연 구에서는 이러한 문제를 더 심층적으로 다룰 필요가 있다.

한편, 청성중기반응의 결과, $\mathrm{IPD}$ 군의 청성중기반응 $\mathrm{Na}, \mathrm{Pa}, \mathrm{Nb}$ 의 잠복기는 정상대조군의 것보다 통계적으로 유의미하게 지연되 었다. $\mathrm{IPD}$ 군의 $\mathrm{Pb}$ 잠복기도 정상대조군보다 지연되었으나 유의미 한 차이는 없었다. 청성중기반응의 진폭에 있어 IPD군의 $\mathrm{Na}-\mathrm{Pa}$ 진 폭은 정상대조군의 것보다 통계적으로 유의미하게 적었지만, $\mathrm{Pa}-$ $\mathrm{Nb}$ 진폭에서 IPD군과 정상대조군은 유의미한 차이를 보이지 않 았다. 한 선행연구에서는 PD 환자군은 정상대조군과 달리 비정상 적으로 지연된 $\mathrm{Pb}$ 의 잠복기와 진폭을 보였으며(Mohamed, Lacono, \& Yamada, 1996), 청성중기반응을 조사한 또 다른 선행연구에 서는 $\mathrm{PD}$ 환자군이 청성중기반응의 $\mathrm{Na}, \mathrm{Pa}, \mathrm{Pb}$ 의 잠복기와 $\mathrm{Pb}$ 의 진 폭에서 정상대조군과 통계적으로 유의미한 차이를 보였다(Kim, 2016). 본 연구결과와 선행연구와의 차이는 병인, 대상자의 연령 및 표본의 수의 차이에 기인할 수 있는데, 이러한 차이에도 불구하고 본 연구의 결과는 선행연구와 마찬가지로 청성중기반응이 파킨슨 병과 밀접한 연관이 있다는 것을 알 수 있었다. 즉, 청성유발반응에 서 청성중기반응이 파킨슨병에 가장 민감하게 차이를 보였는데 청 성중기반응은 중뇌, 망상체 및 시상피질성 경로와 관련된 피질 및 피질하 위치에서 발생하는 신경활동을 반영하는데 구체적으로 청 성중기반응의 $\mathrm{Na}$ 는 중뇌의 하구의 피질하 구조 또는 시상(thala$\mathrm{mus}$ )에서 발생하고 $\mathrm{Pa}$ 는 청각피질의 윗 측두회에서 발생하고 $\mathrm{Nb}$ 와 $\mathrm{Pb}$ 는 망상체, 측두엽의 청각부위 및 해마 등에서 발생한다(McGee, Kraus, Comperatore, \& Nicol, 1991). 시상 및 청각피질과 피질 하에서 주로 발생하는 청성중기반응이 $\mathrm{PD}$ 환자군에서 유의미한 차이를 보이는 것은 파킨슨병의 구조적인 병인으로 시상과 청각피 질 및 피질하 영역의 장애를 암시해 준다고 할 수 있다. 시상은 대뇌 피질과 중뇌 사이의 뇌간 바로 위에 위치한 뇌 내의 작은 구조로서 양쪽 모두에 광범위한 신경 연결을 가지고 있다. 시상은 감각자극 을 신체의 여러 부분에 있는 수용기에서 대뇌피질로 전달하며, 운 동신호와 감각신호를 대뇌피질에 중계하는 역할을 한다. 따라서 파 킨슨병 환자의 말음성 문제는 이러한 시상에서의 기능장애로 인해 운동신호와 감각신호를 통합하는데 문제를 보이는 것으로 유추할 수 있겠다. 따라서 본 연구의 결과에서는 PD 환자군의 청성중기반 응이 PD 환자의 진단과 감별에 사용될 수 있음을 시사하며 후속 연구에서 더 많은 조사가 필요하다. 
한편, 본 연구에서는 청성후기반응의 P1, N1, P2, N2의 잠복기에 있어 IPD군은 정상대조군보다 조금 더 지연되었지만 통계적으로 유의미한 차이를 보이지 않았고, 청성후기반응의 N1-P2의 파간 진 폭에 있어 IPD군이 정상대조군보다 조금 컸지만 통계적으로 유의 미한 차이를 보이지 않았다. Goodin, Squires와 Starr (1978)의 연구 에서는 IPD군에서 P1과 $\mathrm{N} 1$ 의 잠복기는 지연되었으나, P1과 $\mathrm{N} 1$ 의 진폭은 감소되었다고 보고하였다. 이러한 차이는 위에서 언급하였 듯이 연구대상자의 병변의 차이, 손상 부위의 차이, 또는 $\mathrm{H} \& \mathrm{Y}$ 단 계의 차이에 기인한 것으로 여겨진다.

또한, 청성후기반응의 근원은 대뇌피질인데 파킨슨병의 유무가 청성후기반응에 유의미한 차이를 보이지 않은 것은 본 연구의 참가 자 대부분은 대뇌피질의 문제보다는 대뇌피질하 영역인 시상의 문 제를 가진다고 추측할 수 있다.

마지막으로, $\mathrm{PD}$ 환자의 음성강도와 청성유발반응의 상관 관계 를 조사한 결과, 본 연구에서는 청성뇌간반응의 Wave III의 잠복기 에서 음성강도와 유의미한 부적 상관관계를 보였다. 즉, 음성강도 가 작을수록 청성뇌간반응의 Wave III의 잠복기가 길게 나타났다. 청성뇌간반응의 Wave III는 와우핵으로부터 유발되는데 와우핵 은 청신경을 통해 대측 와우에서 핵으로 정보가 전달되는 첫번째 정보처리 단계로 뇌의 체지각부분을 나타낸다. 와우핵은 배측과 등측 와우핵으로 구성되며, 배측 와우핵은 청신경 섬유의 자극시 간과 활동의 패턴에 관한 정보를 처리하고, 등측 와우핵은 대뇌피 질로부터 입력된 정보의 비선형적인 주파수 분석을 통해 소리의 위 치를 파악하는 데 중요한 역할을 수행한다(Malmierca \& Hackett, 2010; Shore, 2009). 이러한 역할이 음성 정보의 주파수 분석에 중요 한 역할을 하므로 본 연구에 PD 환자들은 이러한 등측 와우핵의 손상으로 인해 음성 정보에 대한 주파수 처리 능력에도 제한을 받 을 수 있음을 시사하며 운율장애에 영향을 줄 것으로 보인다.

본 연구결과를 종합해 볼 때, $\mathrm{PD}$ 환자의 작은 음성강도는 정상적 인 청력을 가졌음에도 불구하고 뇌간에서 비정상적인 청각 처리로 기인함을 유추해볼 수 있으며, 이러한 중추감각처리장애가 $\mathrm{PD}$ 환 자의 작은 음성강도와 관련이 있음을 시사하였다. 즉, 본 연구에 참 가한 $\mathrm{PD}$ 환자군은 말초신경의 손상에 의한 청력손실은 없지만 청 각중추신경계에서 와우핵(cochlear nucleus)에 의한 손상은 있을 수 있으며 더불어 청성중기반응의 결과를 고려할 때 대뇌피질이 아 닌 중뇌와 시상 부위의 손상에 의해 청각처리능력이 영향을 받을 수 있을 것으로 사료된다.

본 연구의 의의는 음성강도와 전기생리학적 검사의 측정치를 비 교함으로써 $\mathrm{PD}$ 환자의 말음성 문제가 운동장애뿐 아니라 중추감 각처리과정의 기능이상과 관련 있음을 알 수 있었다. 하지만 본 연
구의 제한점으로는 파킨슨병이 청성유발반응에 미치는 영향을 조 사하였으나, 적은 수의 $\mathrm{PD}$ 환자를 대상으로 실시하였으므로 후속 연구에서는 다수의 PD 환자를 대상으로 본 결과의 타당성을 입증 하는 후속 연구가 필요할 것이다. 또한, 본 연구는 파킨슨병의 유무 에 따라 환자군과 정상대조군으로 분류하였으나 파킨슨병의 중증 도, 즉 $\mathrm{H} \& \mathrm{Y}$ 단계에 따라 연구대상자를 분류하며 추가 모집한다면 파킨슨병의 단계에 따른 청성유발반응을 살펴보기에 유용할 것이 다. 후속 연구에서는 이러한 점을 감안하여 진행된다면, $\mathrm{PD}$ 환자의 청각처리과정을 전체적으로 이해하는 데 도움이 될 것으로 보인다. 또한, 본 연구에서는 PD 환자들의 말음성 문제 중 음성강도 만을 측정하여 전기생리학적 검사 측정치와 비교하였으나, 추후의 연구 에서는 음성강도 외에 음도나 음도 및 강도변이(운율)과 같은 다른 말음성 특성과 청성유발반응 측정치의 상관성을 살펴보는 것이 필 요하다. 또한, 후속 연구에서는 청성유발반응을 통해 음성치료 전 후 음성강도의 변화로 인한 신경가소성의 변화를 조사한다면, $\mathrm{PD}$ 환자들의 음성치료 효과와 소리 크기에 대한 내적 단서나 모니터링 에 대한 중추감각처리과정의 변화를 좀 더 객관적으로 측정할 수 있을 것이다.

\section{REFERENCES}

Arnold, C., Gehrig, J., Gispert, S., Seifried, C., \& Kell, C. A. (2014). Pathomechanisms and compensatory efforts related to Parkinsonian speech. NeuroImage: Clinical, 4, 82-97.

Aronson, A. E. (1990). Clinical voice disorders: an interdisciplinary approach, 3rd ed. New York, NY: Thieme.

Baker, K. K., Ramig, L. O., Luschei, E. S., \& Smith, M. E. (1998). Thyroarytenoid muscle activity associated with hypophonia in Parkinson disease and aging. Neurology, 51(6), 1592-1598.

Bindi, A., Russo, G., Benvenuti, F., Bandinelli, S., Ferrucci, L., \& Rossi, L. (1987). Auditory evoked potentials (AEPs), early (BAEPs) and long latency components (LLCs) in Parkinson's disease: a 12 month follow-up study. Rivista di neurologia, 57(4), 245-250.

Blacker, D. J. (2003). Softly spoken strokes: two patients with marked hypophonia as a feature of strokes involving the anterior thalamus. Journal of Clinical Neuroscience, 10(2), 243-245.

Cancelliere, A. E., \& Kertesz, A. (1990). Lesion localization in acquired deficits of emotional expression and comprehension. Brain and Cognition, 13(2), 133-147.

Chae, H. R., Choi, S. H., Choi, C. H., \& Lee, K. (2019). Effects of Lax Vox 
voice therapy on respiration and phonation in patients with Parkinson's disease. Communication Sciences \& Disorders, 24(3), 785-799.

Choi, C. H. (2015). Neural plasticity and aural rehabilitation. ENT \& Audiology News, 24(4), 81-82.

Choi, C. H., Jang, K. H., \& Choi, S. H. (2015). Effect of stimulus rate and gender on auditory brainstem response in Korean young adults. Audiology, 11(2), 140-155.

Choi, S. H. (2011). The effect of Lee Silverman Voice Treatment (LSVT) on Parkinsonian phonation: nonlinear dynamic, perturbation, and perceptual analysis. Korean Journal of Communication Disorders, 16(3), 335-345.

Choi, S. H. (2012). Effects of deep brain stimulation (DBS) on speech and voice in Parkinson's disease: acoustic measures of vowels from sustained phonation and running speech using perturbation and nonlinear dynamic analysis. Korean Journal of Communication Disorders, 17(1), 143-155.

Duffy, J. R. (2013). Motor speech disorders: substrates, differential diagnosis, and management (3rd ed.). St Louis, MO: Mosby.

Folmer, R. L., Vachhani, J. J., Theodoroff, S. M., Ellinger, R., \& Riggins, A. (2017). Auditory processing abilities of Parkinson's disease patients. BioMed Research International, 2017, 2618587. https://doi.org/10.1155/2017/2618587.

Fox, C. M., Morrison, C. E., Ramig, L. O., \& Sapir, S. (2002). Current perspectives on the Lee Silverman Voice Treatment (LSVT) for individuals with idiopathic Parkinson disease. American Journal of Speech-Language Pathology.

Gath, I., \& Yair, E. (1988). Analysis of vocal tract parameters in Parkinsonian speech. The Journal of the Acoustical Society of America, 84(5), 1628-1634.

Goodin, D. S., \& Aminoff, M. J. (1987). Electrophysiological dfierences between demented and nondemented patients with Parkinson's disease. Annals of Neurology, 21(1), 90-94.

Goodin, D. S., Squires, K. C., \& Starr, A. (1978). Long latency event-related components of the auditory evoked potential in dementia. Brain, 101(4), 635-648.

Guimaraes, I., Cardoso, R., Pinto, S., \& Ferreira, J. J. (2017). The psychometric properties of the voice handicap index in people with Parkinson's disease. Journal of Voice, 31(2), 258.e13-258.e18.

Ho, A. K., Bradshaw, J. L., \& Iansek, R. (2000). Volume perception in parkinsonian speech. Movement Disorders, 15(6), 1125-1131.

Ho, A. K., Bradshaw, J. L., Iansek, R., \& Alfredson, R. (1999). Speech volume regulation in Parkinson's disease: effects of implicit cues and explicit instructions. Neuropsychologia, 37(13), 1453-1460.

Jang, K. H., Choi, S. H., \& Choi, C. H. (2017). Effect of stimulus rate and gen- der on auditory middle latency response in young adults. Audiology and Speech Research, 13(2), 108-114.

Kim, S. J. (2016). Effect of the presence and types of dementia of auditory brainstem responses and middle latency responses (Master's thesis). Daegu Catholic University, Gyeongsan, Korera.

Klostermann, F., Ehlen, F., Vesper, J., Nubel, K., Gross, M., Marzinzik, F., ... \& Sappok, T. (2008). Effects of subthalamic deep brain stimulation on dysarthrophonia in Parkinson's disease. Journal of Neurology, Neurosurgery \& Psychiatry, 79(5), 522-529.

Liotti, M., Ramig, L. O., Vogel, D., New, P., Cook, C. I., Ingham, R. J., ... \& Fox, P. T. (2003). Hypophonia in Parkinson's disease: neural correlates of voice treatment revealed by PET. Neurology, 60(3), 432-440.

Liu, C., Zhang, Y., Tang, W., Wang, B., Wang, B., \& He, S. (2017). Evoked potential changes in patients with Parkinson's disease. Brain Behav, 7(5), e00703.

Logemann, J. A., Fisher, H. B., Boshes, B., \& Blonsky, E. R. (1978). Frequency and cooccurrence of vocal tract dysfunctions in the speech of a large sample of Parkinson patients. Journal of Speech and Hearing Disorders, 43(1), 47-57.

Malmierca, M. S., \& Hackett, T. A. (2010). Structural organization of the ascending auditory pathway. In A. Rees \& A. R. Palmer (Eds.), The Oxford handbook of auditory science: the auditory brain (pp. 9-41). New York, NY: Oxford University Press.

McGee, T., Kraus, N., Comperatore, C., \& Nicol, T. (1991). Subcortical and cortical components of the MLR generating system. Brain Research, 544(2), 211-220.

Möbes, J., Joppich, G., Stiebritz, F., Dengler, R., \& Schröder, C.(2008). Emotional speech in Parkinson's disease. Movement Disorders, 23(6), 824-829.

Mohamed, A. S., Lacono, R. P., \& Yamada, S. (1996). Normalization of middle latency auditory P1 potential following posterior ansa-pallidotomy in idiopathic Parkinson's disease. Neurological Research, 18(6), 516-520.

Mollaei, F., Shiller, D. M., \& Gracco, V. L. (2013). Sensorimotor adaptation of speech in Parkinson's disease. Movement Disorders, 28(12), 1668-1674.

O’Donnell, B. F., Squires, N. K., Martz, M. J., Chen, J. R., \& Phay, A. J. (1987). Evoked potential changes and neuropsychological performance in Parkinson's disease. Biological Psychology, 24(1), 23-37.

Perez, K. S., Ramig, L. O., Smith, M. E., \& Dromey, C. (1996). The Parkinson larynx: tremor and videostroboscopic findings. Journal of Voice, 10(4), 354361.

Pichon, S. \& Kell, C.A. (2013). Affective and sensorimotor components of emotional prosody generation. Journal of Neuroscience, 33(4), 1640-50. 
Ramig, L. O., Countryman, S., Thompson, L. L., \& Horii, Y. (1995). Comparison of two forms of intensive speech treatment for Parkinson disease. Journal of Speech, Language, and Hearing Research, 38(6), 1232-1251.

Ramig, L. O., Fox, C., \& Sapir, S. (2008). Speech treatment for Parkinson's disease. Expert Review of Neurotherapeutics, 8(2), 297-309.

Ramig, L. O., Sapir, S., Fox, C., \& Countryman, S. (2001). Changes in vocal loudness following intensive voice treatment (LSVT) in individuals with Parkinson's disease: a comparison with untreated patients and normal agematched controls. Movement Disorders, 16(1), 79-83.

Raming, L. (1994). Voice treatment for patients with Parkinson disease: development of an approach and preliminary efficacy data. Journal of Medical Speech-Language Pathology, 2, 191-209.

Rascol, O., Payoux, P., Ory, F., Ferreira, J. J., Brefel-Courbon, C., \& Montastruc, J. L. (2003). Limitations of current Parkinson's disease therapy. Annals of Neurology, 53(S3), S3-S15.

Romito, L. M., \& Albanese, A. (2010). Dopaminergic therapy and subthalamic stimulation in Parkinson's disease: a review of 5-year reports. Jour- nal of Neurology, 257(2), 298-304.

Sanju, H. K., \& Kumar, P. (2016). Enhanced auditory evoked potentials in musicians: a review of recent findings. Journal of Otology, 11(2), 63-72.

Shore, S. E. (2009). Auditory/somatosensory interactions. In L. R. Squire (Ed.), Encyclopedia of neuroscience (pp. 691-699). New York, NY: Academic Press.

Solomon, N. P., \& Charron, S. (1998). Speech breathing in able-bodied children and children with cerebral palsy: a review of the literature and implications for clinical intervention. American Journal of Speech-Language Pathology, 7(2), 61-78.

Spielman, J., Ramig, L. O., Mahler, L., Halpern, A., \& Gavin, W. J. (2007). Effects of an extended version of the Lee Silverman Voice Treatment on voice and speech in Parkinson's disease. American Journal of Speech-Language Pathology, 16(2), 95-107.

Yýlmaz, S., Karalý, E., Tokmak, A., Güçlü, E., Koçer, A., \& Öztürk, Ö. (2009). Auditory evaluation in Parkinsonian patients. European Archives of OtoRhino-Laryngology, 266(5), 669-671. 


\section{국문초록}

\section{파킨슨병 환자의 음성강도 및 청성유발반응 특성}

최철희 ${ }^{1,2} \cdot$ 박채림,3 $\cdot$ 최성희 ${ }^{1,2}$

${ }^{1}$ 대구가톨릭대학교 바이오메디대학 언어청각치료학과, ${ }^{2}$ 생체모방감각제어연구소 및 가톨릭 청각음성언어센터, ${ }^{3}$ 대구가톨릭대학교 일반대학원 언어청각치료학과, 4강북삼성병원 이비인후과

배경 및 목적: 파킨슨병은 감각과 운동의 통합능력 저하로 야기되는 만성 퇴행성 질환으로 자신의 음성강도를 조절하는데 어려움을 겪는 감각장애이다. 본 연구는 파킨슨병이 청각의 말초와 중추신경계에 미치는 영향 및 음성강도와 청성유발반응의 관계를 살펴보고 자 한다. 방법: 총 24 명(파킨슨병 환자군 12 명과 정상대조군 12 명)을 대상으로 순음청력검사 및 청성유발반응 검사를 실시하였으며 소 음계를 사용하여 모음// 연장 발성과 표준 문단 '가을' 문장 읽기 시 음성강도를 측정하였다. 청력검사는 순음청력검사기를 사용하여 250 에서 $8,000 \mathrm{~Hz}$ 의 주파수영역에서 청력역치를 측정하였으며, 청성유발반응은 청성뇌간반응, 청성중기반응 및 청성후기반응을 측정 하였다. 결과: 순음청력결과, 파킨슨병 환자군의 청력역치는 정상대조군보다 유의미한 차이를 보이지 않았다. 음성강도는 파킨슨병 환 자군의 평균 음성강도가 정상대조군에 비해 유의미하게 낮았다 $(p<.05)$. 한편, 파킨슨병 환자군의 청성중기반응의 $\mathrm{Na}, \mathrm{Pa}, \mathrm{Nb}$ 의 잠복 기는 정상군보다 유의미하게 지연되었다. 또한, 파킨슨병 환자군의 $\mathrm{Na-Pa}$ 의 파간 진폭이 유의미하게 낮았다. 청성후기반응은 파킨슨병 환자군과 정상군 간 유의한 차이를 보이지 않았다. 파킨슨병 환자의 음성강도는 청성뇌간반응 Wave III의 잠복기와 유의미한 상관관계 를 보였으며, 파킨슨병의 환자의 음성 강도가 작을수록 Wave III의 잠복기도 지연되었다. 논의 및 결론: 전기생리학적 검사는 파킨슨병 환자의 감각기능이상과 관련된 임상적으로 유용한 정보를 제공해 주었으며, 파킨슨병 환자군의 낮은 음성강도는 말초청각기능의 문제 이상이 아닌 중추청각기능과 관련이 있으며, 감각조절의 기능 문제로 발생함을 시사한다.

핵심어: 파킨슨병, 청력역치, 청성유발반응, 청성중기반응, 음성강도

\section{참고문헌}

김수진(2016). 치매의 유무와 유형에 따른 청성유발반응 비교. 대구가톨릭대학교 대학원 석사학위논문.

채혜림, 최성희, 최철희, 이경재(2019). Lax Vox 음성치료가 파킨슨병 환자의 호흡 및 발성에 미치는 효과. Communication Science \& Disorders, 24(3), 791-805.

최성희(2011). 파킨슨씨병 음성에 대한 리실버만 음성치료의 효과: 비선형의 역동적, 섭동적, 청지각적 분석. 언어청각장애연구, 16(3), 335-345.

최성희(2012). 파킨슨씨병 환자의 뇌심부자극술에 대한 말음성 효과: 섭동적 분석과 비선형 역동적 분석을 이용한 연장 발성과 연속 발화 모음의 음 향학적 분석. 언어청각장애연구, 17(1), 143-155.

\section{ORCID}

최철희(제1저자, https://orcid.org/0000-0003-1844-3072); 박채림(공동저자, https://orcid.org/0000-0003-1672-6773); 최성희(교신저자, https://orcid.org/0000-0003-2365-6187) 